\title{
Water and sediment balances of a contour bench terracing system in a semi-arid cultivated zone (El Gouazine, central Tunisia)
}

\author{
YOUSSEF AL ALI ${ }^{1}$, JAWDAT TOUMA ${ }^{1}$, PATRICK ZANTE ${ }^{1}$, SLAH NASRI $^{2} \&$ \\ JEAN ALBERGEL ${ }^{1}$ \\ 1 IRD, UMR LISAH, 2 Place Viala, F-34060 Montpellier, France \\ y.alali@hotmail.fr \\ 2 INRGREF, BP 10, 2080 Ariana, Tunisia
}

\begin{abstract}
Contour benches are earthen structures constructed across cultivated slopes, at intervals down the slope, largely used in semi-arid zones. The results of an experiment to monitor water and sediment balance inside a contour bench terrace system are presented. The study site, located in the El-Gouazine watershed (central Tunisia), includes two terraced plots of approximately $3000 \mathrm{~m}^{2}$, one of which was left fallow for several years, while the other was tilled. The characteristics of rainfall-runoff processes and erosion inside both terraced plots during a two-year period (2004-2006) are described. Ploughing reduced runoff by $75 \%$. Erosion was monitored following runoff episodes that produced observable deposits in the bench channel. After ploughing, erosion was reduced by $44 \%$ between July 2004 and July 2005 and by $50 \%$ between October 2005 and July 2006. However, erosion per millimetre of runoff was about twice as great on the tilled soil as on the fallow. Even though ploughing weakens the soil, it seems to reduce erosion by increasing infiltration. For the studied rain events, ploughing used in combination with contour bench terraces seems to have limited erosion and enhanced the effectiveness of contour bench terrace management.
\end{abstract}

Key words contour bench terraces; erosion; land use; semi-arid region; runoff; central Tunisia

\section{Bilan hydro-sédimentaire d'un aménagement en banquettes anti-érosives en zone cultivée} semi-aride (EI Gouazine, Tunisie centrale)

Résumé Les banquettes anti-érosives sont des structures en terre construites au sein de versants cultivés, espacées dans le sens de la pente, très utilisées dans les zones semi-arides. Cet article présente les résultats d'un dispositif expérimental mis en place pour caractériser le fonctionnement hydro-sédimentaire d'un système de banquettes. Le site d'étude, inscrit dans le bassin versant d'El-Gouazine (Tunisie centrale), comprend deux parcelles terrassées d'environ $3000 \mathrm{~m}^{2}$ chacune. La première parcelle est en jachère de parcours depuis plusieurs années, alors que la deuxième est labourée. Les caractéristiques des processus de la transformation pluie-ruissellement et de l'érosion mesurés au sein des deux parcelles pendant une période de deux ans (2004-2006) sont décrites. Le travail du sol a réduit le ruissellement de 75\%. L'érosion a été observée suite aux épisodes ruisselants apportant des dépôts observables dans le canal. Le labour a réduit l'érosion de 44\% entre Juillet 2004 et Juillet 2005, et de 50\% entre Octobre 2005 et Juillet 2006. Par contre, l'érosion par millimètre de ruissellement a été environ deux fois plus importante dans la parcelle labourée. Même si le labour fragilise le sol, il semble qu'il réduise l'érosion en augmentant l'infiltration. Pour les événements pluvieux étudiés, le travail du sol dans l'inter-banquettes semble avoir limité l'érosion et augmenté l'efficacité de l'aménagement en banquettes.

Mots clefs banquettes anti-érosives; érosion; occupation du sol; région semi-aride; ruissellement; Tunisie centrale

\section{INTRODUCTION}

Problems of erosion on farmland are severe throughout the Mediterranean region, particularly in the arid and semi-arid zones of North Africa and the Middle East. This phenomenon is a major factor in the degradation of soil and water. It limits agricultural production and is a significant constraint to long-term rural development. Erosion has increased significantly during the second half of the 20th century as the cultivated area has expanded (Roose, 1994).

To limit soil loss and protect water resources, countries in this region initiated aggressive soil management and conservation policies in the 1960s (Roose, 1994). Since then, 1.5 million hectares of farmland have been developed to limit erosion in Tunisia (Nasri et al., 2004). Improved traditional techniques (Ennabli, 1993; Prinz, 1999) and techniques imported from the USA (Heusch, 1986) have been implemented. These include: (a) hill reservoirs and dams (Albergel et al., 2003a); (b) rectification of gullies; (c) afforestation; (d) re-seeding of perennial graminaceae 
and herbaceous plants; and (e) erosion control benches; as well as various water harvesting and runoff control techniques on slopes (tabias and meskats) (Alaya et al., 1993), or in hydrographic networks (jessours) (Prinz, 1999). Erosion control benches protect over 900000 ha of Tunisian farmland (Nasri, 2002).

The contour benches are earth embankments built along contour lines, perpendicular to the slope, to intercept and store runoff water. They improve infiltration locally. The benches also reduce both the length of slope susceptible to runoff and the runoff velocity, which remains below the critical threshold of gully erosion (Nahal, 1975). They are increasingly built with earthmoving machines and are referred to as machine-made benches. There are two types of erosion control benches: total retention benches and diversion benches, the former being the most common.

Over the past few decades, Tunisian Water and Soil Conservation agencies have acquired significant experience in the construction, consolidation and maintenance of these structures (Cherif et al., 1995). However, little research is available on the benches' hydrological function, or their impact on the balance of water and transported material. At the watershed scale, some research has shown an appreciable reduction in runoff and erosion when the structures cover more than $40 \%$ of the catchment hill slopes (Albergel et al., 1998; Nasri et al., 2004). Some research has been carried out on the hydrological functioning of slopes equipped with benches; Heusch (1986) evaluated this type of structure in Morocco, Algeria and Tunisia and noted that it was introduced to Algeria at the end of the 18th century. He indicated that it is most effective in regions where rainfall is rare, brief and very intense, falling on dry soil with low permeability. Other studies focus on terraced bench systems: in a humid tropical climate in Indonesia (Dijk, 2002), a subtropical climate in Australia (Freebairn \& Wockner, 1986), and a sub-humid climate in India (Sharda \& Samra, 2002).

This paper describes equipment used to study the functioning of a total retention contour bench system in Tunisia and presents the preliminary results for two years. Water and sediment balances are established for two management scenarios: fallow pasture land and tilled land. The overall framework of this study was given in Nasri (2007) and focused on the hillslope; the present study gives the results of the experiment at the contour ridges scale.

\section{MATERIALS AND METHODS}

\section{The study site}

The study site is located on the small watershed of the El Gouazine hill reservoir $\left(18.1 \mathrm{~km}^{2}\right)$ in the Kairouan Governate of central Tunisia (Fig. 1).

Annual rainfall is very irregular and variable, with an annual average (1993-2006) of $366 \mathrm{~mm}$ and a standard deviation of $124 \mathrm{~mm}$. Storms can be intensive, often exceeding $100 \mathrm{~mm} / \mathrm{h}$ in $5 \mathrm{~min}$. In 1996 and 1997, contour benches were built on 40\% of the watershed to ensure optimum protection against silting at the outlet of the hill reservoir. These structures cover the majority of the cultivated area of the watershed. The study site is located on the downstream part of the basin on deep, alluvial loam soil (Zante \& Mansouri, 1999, in Mansouri, 2001).

A contour bench, as shown in Fig. 2, consists of a cordon of earth placed just downhill of a channel, and following a contour line. This cordon is made with earthmoving machines that dig the channel, move the earth, and shape the benches. The construction of contour benches follows welldefined norms (Cherif et al., 1995). The bench length varies according to drainage, paths, roads and property lines. The channel is about $6 \mathrm{~m}$ wide with little or no longitudinal slope. The depth of the channel depends on the height of the bench, which is itself calculated according to the spacing between benches (Dridi, 2000). The distance between two benches is calculated as a function of the slope using empirical formulas given in water and soil conservation handbooks (Cherif et al., 1995).

Two plots with similar morphological and soil characteristics were delineated on cereal fields. The first plot is located on land that has lain fallow and been grazed for a dozen years; the second 


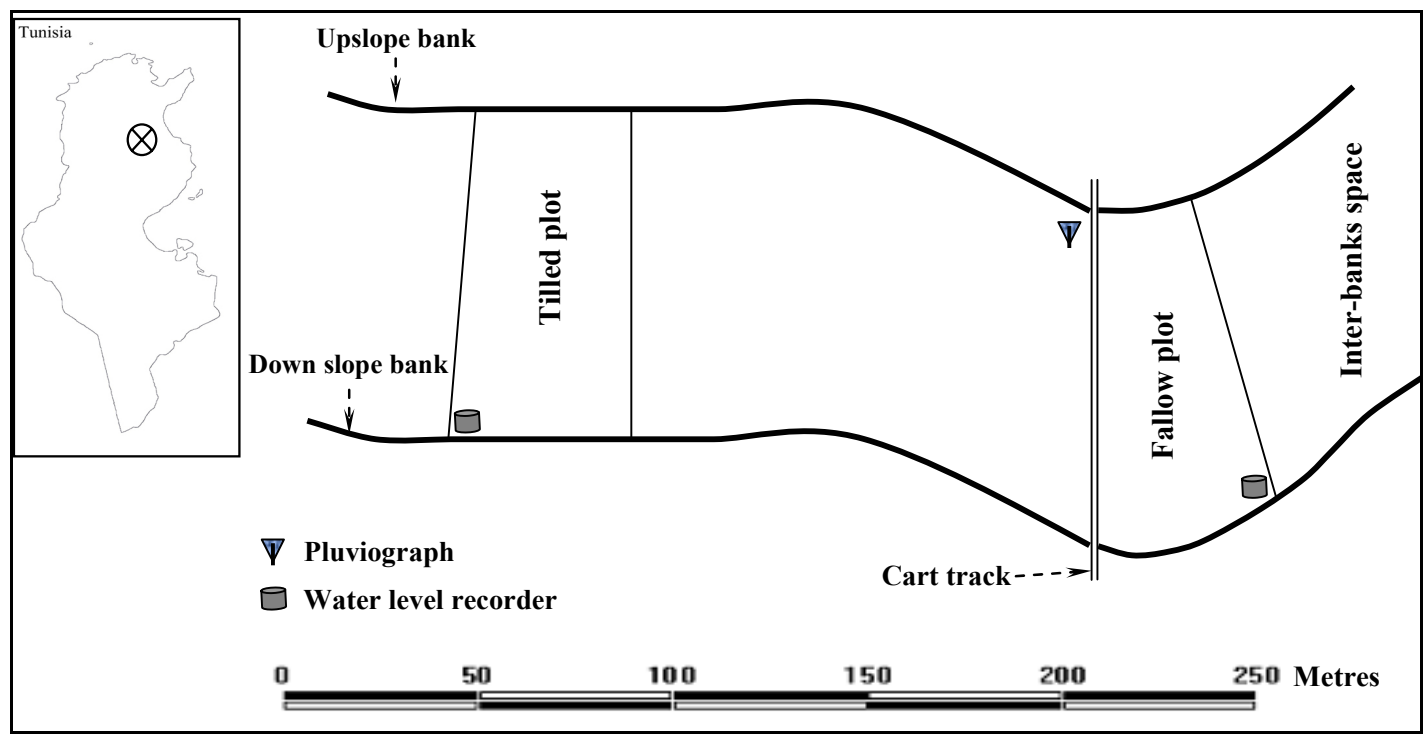

Fig. 1 Plan of the site showing lay out of measurement plots.

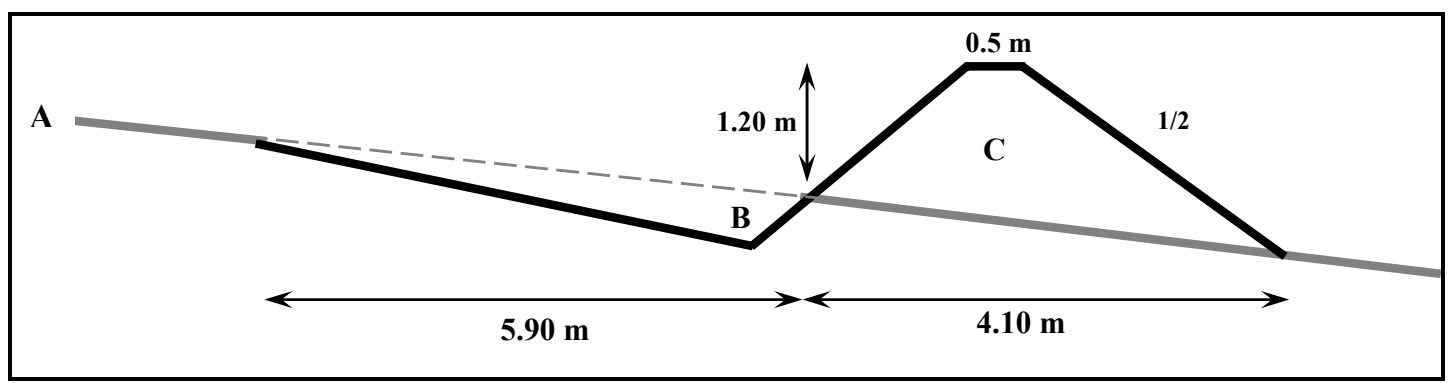

Fig. 2 Profile of a contour bench terrace (banquette) showing: the natural slope (A), the channel of the bench $(B)$ and the ridge $(C)$.

is a cultivated field ploughed and sown every year when autumn rains permitted. The two plots occupy the same inter-bench space on both sides of a farm path (Fig. 1). They are bordered upslope and downslope by two benches. The lateral boundaries $(10 \mathrm{~cm}$ height $)$ consist of a cement curb for the fallow plot and an earthen cordon for the tilled one. The fallow plot soil surface $\left(2840 \mathrm{~m}^{2}\right)$ is covered by an erosion crust according to the typology of soil surface characteristics established by Casenave \& Valentin (1989) with scattered, grazed graminaceae vegetation. A few scrubby tufts of thyme, rosemary and Artemisia herba-alba are present. The second plot $\left(2950 \mathrm{~m}^{2}\right)$ was superficially tilled at the beginning of the autumn before the rainfall season. Tillage is carried out in the region using a disk plough. The cloddy surface of the tilled plot is very rough and becomes covered by an open structural crust following the first rains.

The dimensions of the plots and the installation of measuring instruments were made so that the downslope channel of each plot could retain the runoff of a rain event having a 10-year average recurrence interval without overflowing. A 1:10 year recurrence interval rain of $94 \mathrm{~mm}$ (Annuaire hydrologique des lacs collinaires de Tunisie 1997-98, March 1999) and runoff coefficients of 0.76 and 0.22 were assumed for the grazed fallow soil and the tilled soil, respectively. Volumes of water that could be retained by the channels were respectively 202 and $61 \mathrm{~m}^{3}$. Two lateral embankments were built across each channel to retain runoff to the above design criteria (1:10 year). On one of these embankments, a V-shaped weir, was installed at the spill level to measure runoff if it exceeded the channel storage volume. 


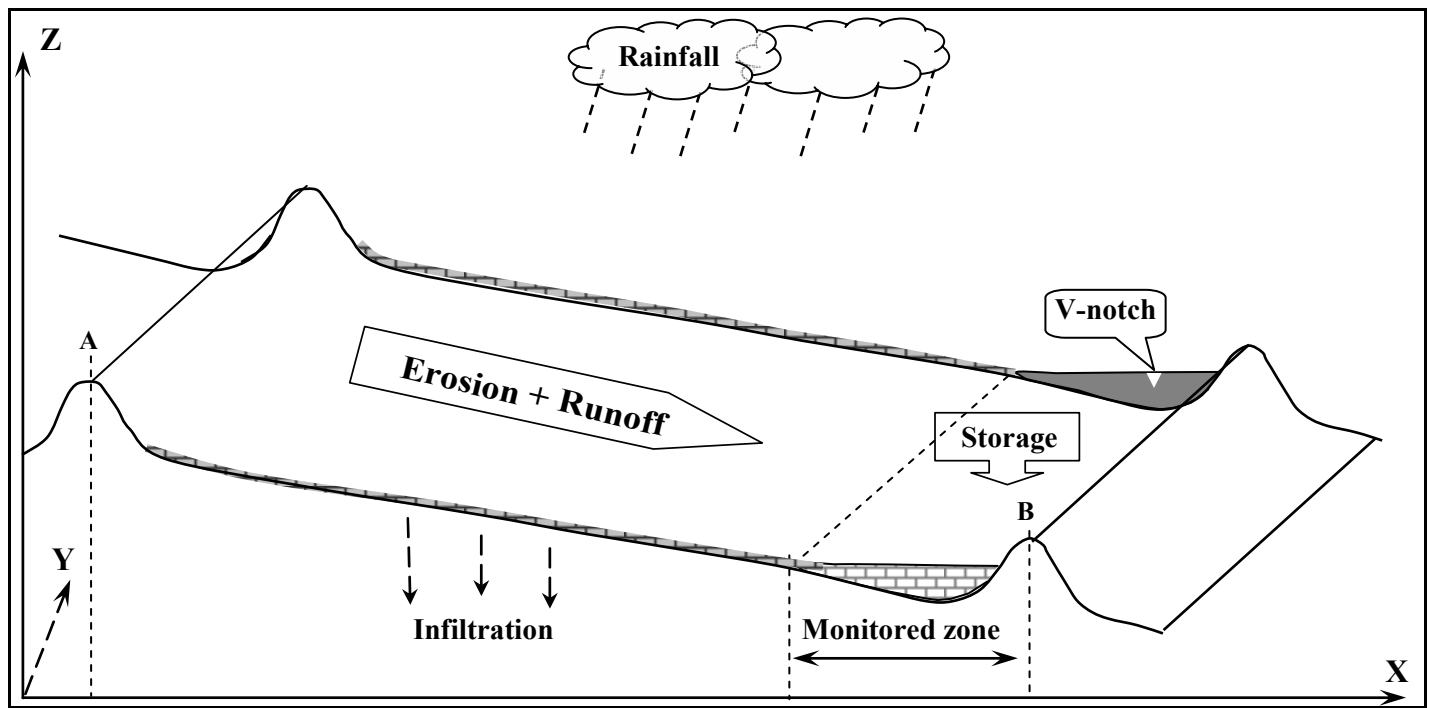

Fig. 3 Schematic diagram showing runoff and erosion processes in the inter-bench space A-B, where A is the upslope bench and $\mathrm{B}$ the downslope one.

\section{Methodology of monitoring and analysis of water and sediment balances}

The water and sediment movement was monitored in the channel of each plot. During rainfall episodes, runoff and transported solids are stored in the channel up to the spill level (Fig. 3). If this water level is reached, runoff can be assessed using the V-shaped weir, and the solid transport from samples.

Monitoring water balance The runoff kinetics in the inter-bench space is considered to be Hortonian. The depth of the water table at the site is sufficiently great to justify this hypothesis (Albergel et al., 2003b).

The volume of water that accumulates upslope of the bench is calculated based on the recording of the height of the water surface and precise topography, readjusted after each event that yields sediment deposits. This topography allows the updating of the level-volume curves of the channel, as shown in Fig. 4.

Variations in water level in the channel are monitored by two water-level recorders that continuously measure the water level with an accuracy of $\pm 1 \mathrm{~cm}$ (height) and $\pm 2 \mathrm{~min}$ (time).

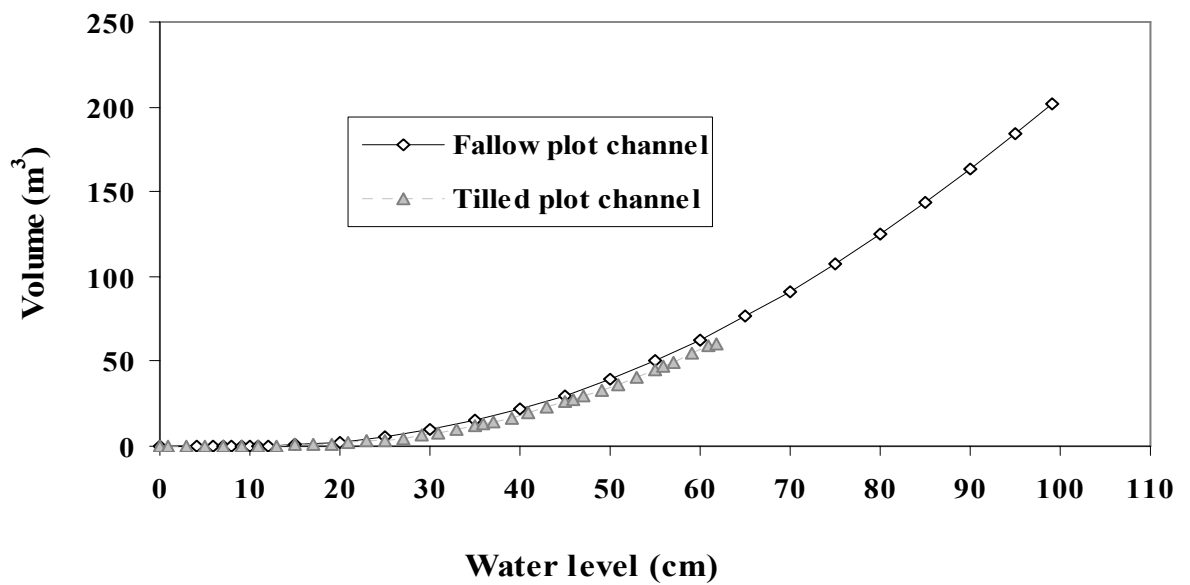

Fig. 4 Level-volume curves of the upslope channel of both plots. 
The runoff rate in the inter-bench space is calculated through the water level measurement interval. The law of mass conservation is applied to the accumulated volumes of water in the channel, neglecting the volumes that infiltrate or evaporate during a rainfall event (Albergel \& Rejeb, 1997).

The amount and intensity of rainfall are measured by a tipping-bucket raingauge installed on the site between the two plots $(0.5 \mathrm{~mm}$ tips logged at $1 \mathrm{~s}$ intervals $)$.

The infiltration kinetics in the channel is monitored by the decrease in the stored water levels, weighted by the measured daily evaporation using a buried, ORSTOM type, class A $1 \mathrm{~m}^{2}$ basin with a depth of $60 \mathrm{~cm}$ (Remenieras, 1972).

Monitoring of sediment balance The materials produced by inter-bench erosion are stored in the pre-bench channel as shown in Fig. 3. Comparison of digital terrain models (DTM) allowed for identification of soil loss (abrasion of the channel) and soil deposits (sedimentation of eroded materials) zones. The erosion of the inter-bench space is then estimated from the difference between DTMs.

Several topographic level recordings were made during the rainy season 2004/05 after each significant runoff episode. They were carried out using a laser tachymeter following a dense grid $\left(0.5 \times 1 \mathrm{~m}^{2}\right)$ taking into account the irregularities of the landscape to measure all visible humps and troughs. In 2005/06, a system of stakes providing the same measurement density, was set up to improve the accuracy of the evaluation of the thickness of deposits.

The DTMs were established from spatial interpolation using the Delaunay triangulation method. The procedure to quantify erosion therefore consists of the calculation of the volume enclosed between two surfaces derived from two successive DTMs. The surfaces to take into account are those of the part of the channel where sediment accumulation takes place. This limitation of the surface using a "blank" corresponding to the visible deposits allows the elimination of framing effects (accuracy on the levelling of stable zones and accuracy on the interpolation of points framing the levelling).

The method used to estimate the accuracy of the measurement of erosion by topographic readings (Collinet \& Zante, 2005) was to consider the measurement error linked to the calculation of volumes from DTMs to be, at most, equal to the sum of uncertainties in the DTM and measurement uncertainties of a reference point when levelling by a tachymeter. For the stake measurements, five measurements of the height of each stake were undertaken during one procedure and the measuring error was estimated from the analysis of variance.

\section{RESULTS AND DISCUSSION}

\section{Water balance}

Forty storms generated runoff on the fallow plot during the two years of observation. In contrast, only 11 events produced runoff on the tilled plot. No channel overflow was observed on either plot. Figure 5 shows the volumes of water stored and then infiltrated in the channels of the two plots for the rainfall events of 2 and 13 November 2004. Table 1 summarizes the principal hydrological characteristics of the annual balances on the two plots during the two-year observation period.

Table 1 shows that for a similar amount of annual rainfall (489 and $482 \mathrm{~mm}$, respectively), runoff was less during the second year. This variation in runoff may be explained by the intensity of the rain, which was more moderate and distributed over more events during the second year. An estimation of error was made by considering the accuracy of the level-volume curve as $5 \%$ and that of the estimated reading of channel water levels at $1 \mathrm{~cm}$. As an example, the error estimation for the flood of 2 November 2005, shown in Fig. 5, gives a volume of runoff between 57 and $69 \mathrm{~m}^{3}$. The uncertainties in the estimations of volume in the channel are greater than the neglected terms in the balance equation (1): i.e. evaporation and infiltration during the event. 


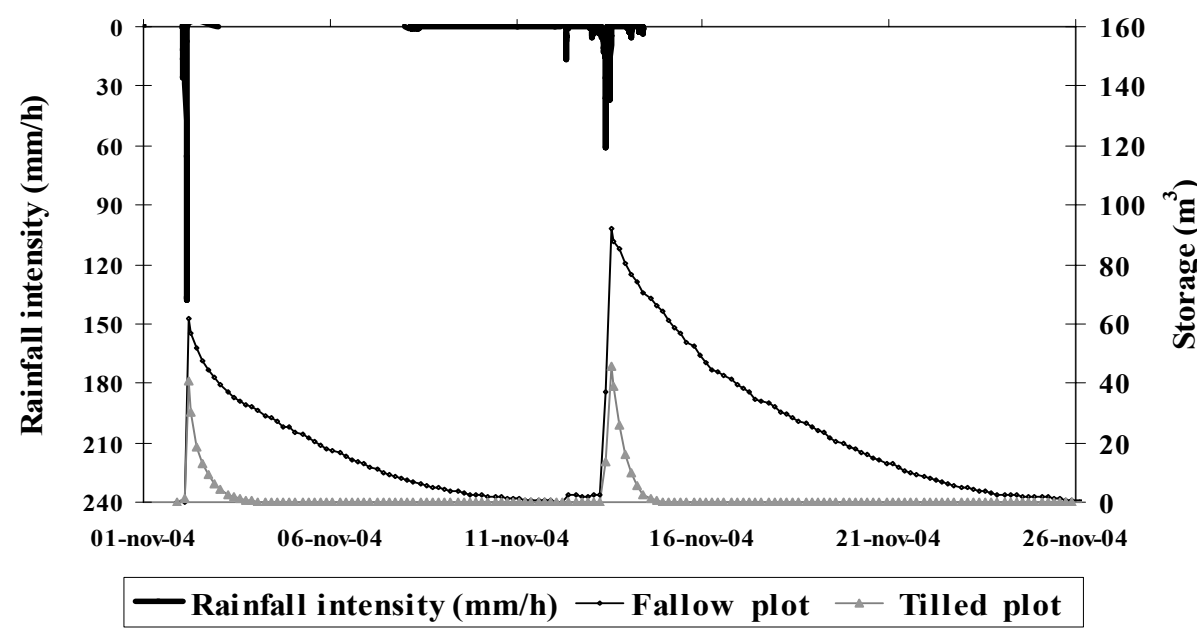

Fig. 5 Volumes stored in the channels of the two plots in November 2004.

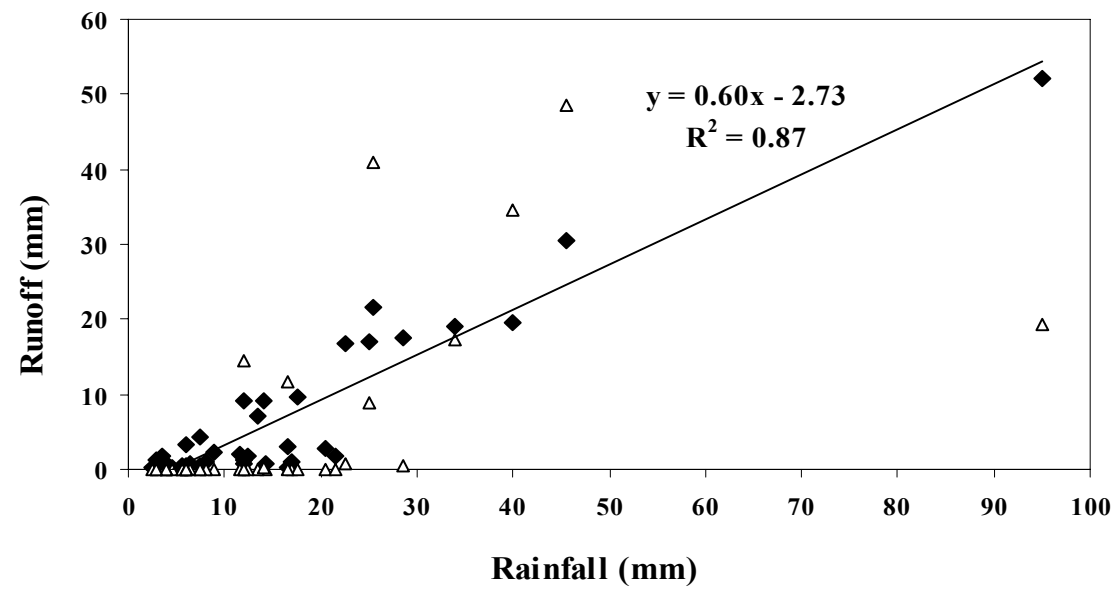

- Runoff in Fallow plot (mm) $\Delta$ Runoff in Tilled plot (mm)

Fig. 6 Relationship between runoff and rainfall on the fallow and tilled plots.

Table 1 Annual balance of runoff events on the two treatments.

\begin{tabular}{|c|c|c|c|c|c|c|c|c|c|c|}
\hline \multirow[t]{2}{*}{ Year } & \multirow{2}{*}{$\begin{array}{l}A p \\
(\mathrm{~mm})\end{array}$} & \multirow{2}{*}{$\begin{array}{l}\operatorname{Imax} \\
(\mathrm{mm} / \mathrm{h})\end{array}$} & \multicolumn{4}{|c|}{ Fallow plot: } & \multicolumn{4}{|c|}{ Tilled plot: } \\
\hline & & & $\mathrm{Nb}$ & $\begin{array}{l}R d \\
(\mathrm{~mm})\end{array}$ & $\begin{array}{l}\operatorname{Irmax} \\
(\mathrm{mm} / \mathrm{h})\end{array}$ & $\begin{array}{l}K r \\
(\%)\end{array}$ & $\begin{array}{l}\mathrm{Nb} \\
\text { event }\end{array}$ & $\begin{array}{l}\mathrm{Lr} \\
(\mathrm{mm})\end{array}$ & $\begin{array}{l}\operatorname{Irmax} \\
(\mathrm{mm} / \mathrm{h})\end{array}$ & $\begin{array}{l}A r \\
(\%)\end{array}$ \\
\hline $2004 / 05$ & 489 & 137 & 18 & 155 & 143 & 32 & 6 & 49 & 119 & 10 \\
\hline 2005/06 & 482 & 78 & 22 & 110 & 81 & 23 & 5 & 18 & 27 & 4 \\
\hline
\end{tabular}

$A p$ : annual precipitation on the site; Imax: maximum rainfall intensity over a 5-min time step ; $N b$ : number of rainfallrunoff events; $R d$ : total runoff depth; Irmax: maximum runoff intensity over a 5-min time step Ar: annual runoff coefficient.

Analysis of the results shows a significant difference in runoff between the two catchments: the average annual runoff coefficient values are $28 \%$ for the fallow plot and $7 \%$ for the tilled plot. Runoff was reduced by $75 \%$ in the tilled plot over the total monitoring period (2004-2006).

The analysis of runoff events shows that this difference persists throughout the year, despite the formation of a structural crust on the tilled plot following the first rains. Figure 6 suggests a linear relationship between the depth of runoff and the height of rainfall for the fallow plot. Such a simple relationship could not be established for the tilled plot due to the low number of runoff episodes and to the variation in land surface characteristics during the rainy season. 


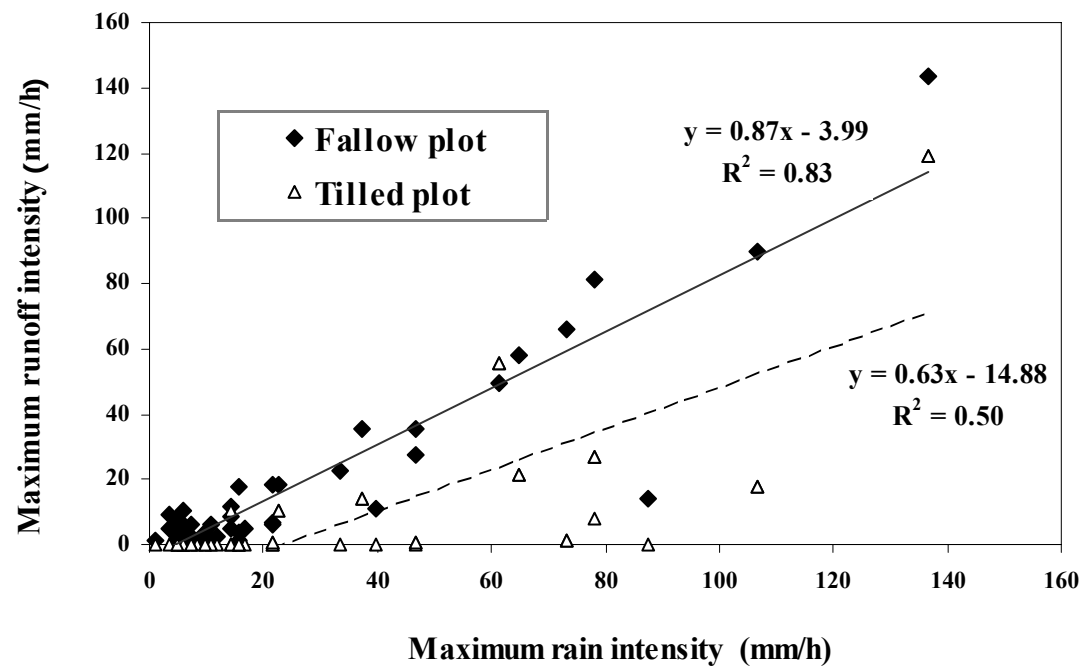

Fig. 7 Maximum runoff intensity corresponding to the maximum rain intensity over a 5-min interval.

The maximum runoff discharge on the two plots increases with the intensity of rain. Figure 7 shows the relationship between the maximum runoff intensity and the maximum intensity of the rainfall; these two variables were averaged over a time step of $5 \mathrm{~min}$ and are expressed in $\mathrm{mm} / \mathrm{h}$. The greater dispersion of points on the tilled treatment plot is explained by the progressive formation of slaked surfaces after the soil has been ploughed. However, the two correlations are significant for a confidence level of $95 \%$. They indicate thresholds of rainfall intensity that trigger runoff which are markedly different on the two plots: $5 \mathrm{~mm} / \mathrm{h}$ for the fallow treatment and $24 \mathrm{~mm} / \mathrm{h}$ for the tilled treatment.

Calculations of the rise time and lag time for each flow do not show significant differences between the two plots. The lag times are of the order of $8 \mathrm{~min}$ and the rise times approx. $20 \mathrm{~min}$.

Following floods, the volume of stored water disappears progressively over several days through evaporation and infiltration. We calculated the daily infiltration rate for each treatment after deducting evaporation. Figure 8 shows the relationship between infiltration flux and the water level in the upslope bench channel for the two plots.

Higher infiltration rates were observed in the channel of the tilled catchment, although management did not differ from that of the fallow plot (the channel is not tilled in either

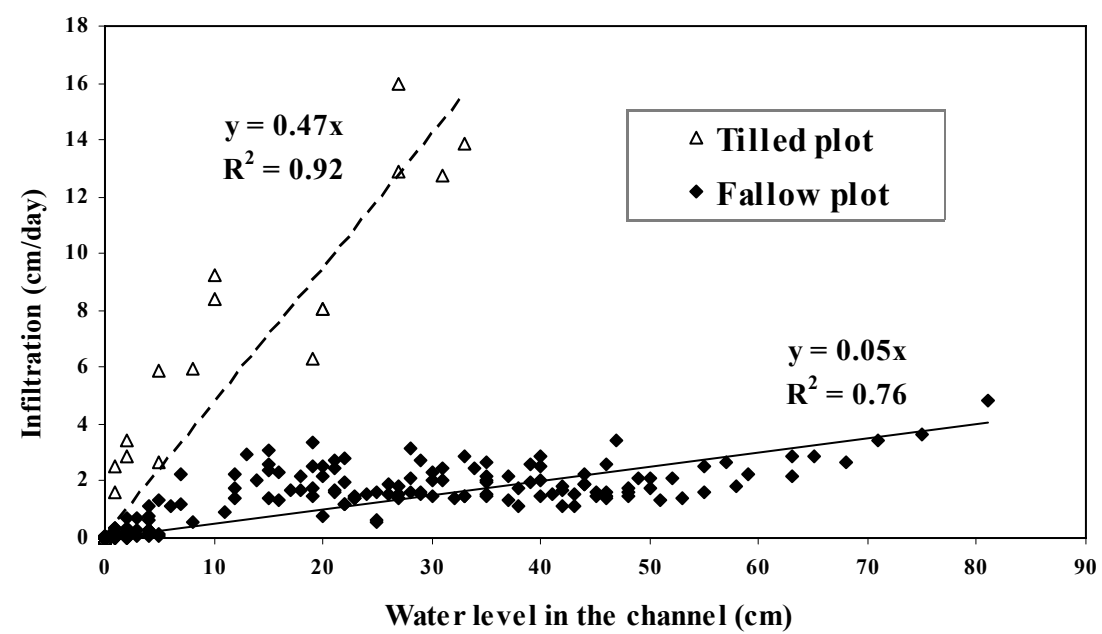

Fig. 8 Relationship between infiltration and water level in the downslope channel. 
catchment). Field observations revealed greater soil mesofauna activity on the bench and in the channel of the tilled treatment, very likely linked to the crops growing between the benches when under cultivation. This mesofauna induces macroporosity on the bottom of the channel and on the upslope side of the bench.

\section{Sediment balance}

Topographic measurements of the downslope channel of each plot enabled the establishment of successive balances (deposit/erosion) for the tilled and fallow plots (Table 2). The "blank" area adjusted to the contours of the zone of channel where deposits could be observed was evaluated in the field. It has a surface area of $100 \mathrm{~m}^{2}$ for the fallow treatment and $90 \mathrm{~m}^{2}$ for the tilled treatment. We estimated the uncertainty which expresses the maximum DTM calculation error at each survey reading. This uncertainty is of the order of $0.005 \mathrm{~m}$ for tachymetric measurements (Collinet \& Zante, 2005) and $0.002 \mathrm{~m}$ (variance analysis for 825 measurements) for stake measurement on the average height of DTM for a $95 \%$ confidence interval. Density measurements allowing the conversion of sediment volume to weight gave values between 1.2 and $1.4 \mathrm{t} / \mathrm{m}^{3}$. There was a small difference in sediment density between plots.

Table 2 shows that the volumes calculated per intermediary period are of the same order of magnitude as the probable error of measurement. For the difference between two recordings of level to be significant, the thickness of deposits must be greater than $1 \mathrm{~cm}$ for tachymetric measurements and greater than $0.4 \mathrm{~cm}$ for stake measurements. In this way it is possible to give a total value of soil loss for the first period with the accuracy of tachymetric measurements (July 2004July 2005) and a value for the second period (October 2005-July 2006) with the accuracy of stake measurements. Table 3 summarises these values, reporting them in $\mathrm{mm}$ of rainfall and $\mathrm{mm}$ of runoff.

Table 2 Hydrological and sediment balance of fallow and tilled terraced plots.

\begin{tabular}{lcccccc}
\hline Period & $\begin{array}{l}\text { Rainfall } \\
(\mathrm{mm})\end{array}$ & $\begin{array}{l}\text { Runoff } \\
(\mathrm{mm})\end{array}$ & $\begin{array}{l}V p \\
\left(\mathrm{~m}^{3}\right)\end{array}$ & $\begin{array}{l}V n \\
\left(\mathrm{~m}^{3}\right)\end{array}$ & $\begin{array}{l}V r \\
\left(\mathrm{~m}^{3}\right)\end{array}$ & $\begin{array}{l}E m \\
(\mathrm{t})\end{array}$ \\
\hline Fallow plot: & & & & & & \\
July-September 2004* & 44 & 0 & +0.99 & -1.36 & -0.37 & -0.52 \\
September-December 2004 & 120 & 57 & +2.04 & -0.47 & +1.56 & 2.26 \\
December 2004-July 2005 & 290 & 67 & +2.78 & -0.22 & +2.56 & 3.15 \\
July 2004-July 2005 & 454 & 124 & +3.88 & -0.13 & +3.75 & 4.61 \\
\hline Terraced plot: & & & & & & \\
July-September 2004* & 44 & 0 & +1.39 & -2.09 & -0.70 & -0.91 \\
September-December 2004 & 120 & 30 & +2.12 & -0.41 & +1.71 & 2.17 \\
December 2004-July 2005 & 290 & 11 & +1.50 & -0.48 & +1.02 & 1.29 \\
July 2004-July 2005 & 454 & 41 & +2.84 & -0.81 & +2.03 & 2.56 \\
\hline
\end{tabular}

$V p$ : positive volume (= deposits in the channel); $V n$ : negative volume (= erosion in the channel); $V r$ : residual volume (= erosion of the plot); Em: mass erosion of the plot.

* No runoff was observed during this period, the volume of sediment may be considered as nil. The weak negative

values may correspond to settling after summer drying and are of the order of accuracy of the measurements.

Table 3 Balance of water and sediment of the two plots during the two observation periods (1: July 2004July 2005 and 2: October 2005-July 2006).

\begin{tabular}{lllll}
\hline & Fallow plot: & Tilled plot: & \\
& Period 1 & Period 2 & Period 1 & Period 2 \\
\hline Rain $(\mathrm{mm})$ & 454 & 348 & 454 & 348 \\
Runoff $(\mathrm{mm})$ & $124 \pm 6$ & $91 \pm 5$ & $41 \pm 2$ & $18 \pm 1$ \\
Specific erosion $\left(\mathrm{t} \mathrm{ha}^{-1}\right)$ & $16 \pm 2$ & $6 \pm 1$ & $9 \pm 2$ & $3 \pm 1$ \\
Rain erosivity $\left(\mathrm{kg} \mathrm{ha}^{-1} \mathrm{~mm}^{-1}\right)$ & $35 \pm 5$ & $16 \pm 3$ & $20 \pm 4$ & $9 \pm 2$ \\
Runoff erosivity $\left(\mathrm{kg} \mathrm{ha}^{-1} \mathrm{~mm}^{-1}\right)$ & $129 \pm 22$ & $66 \pm 15$ & $220 \pm 60$ & $167 \pm 65$ \\
\hline
\end{tabular}


There are significant differences of estimated erosion between the first and the second year for each plot. On the two plots, erosion is much lower during the second year. This may be explained by the characteristics of rainfall (as was already explained; Table 1).

The ratios erosion/rain and erosion/runoff show that ploughing weakens the soils, but limits erosion by favouring infiltration. Ploughing reduced erosion by $44 \%$ between July 2004 and July 2005 and 50\% between October 2005 and July 2006. However, the sediment concentration in runoff is nearly twice as high on the tilled plot as on the fallow. This land-use effect was also noted by Cerdan et al. (2001), in the context of the role of the soil crust development for large crops in temperate environments. For the current events, we may assert that, for this type of soil, ploughing limits erosion. This trend still needs to be verified during exceptionally heavy rains.

\section{CONCLUSIONS}

The experimental equipment described in this article enabled measurement of water and sediment balances in an inter-bench space between contour benches. It allowed quantification of runoff and erosion on two crop system options in a semi-arid Mediterranean terraced hillslope.

The study demonstrated the importance of land-use modes on runoff and erosion processes. The tilled mode significantly reduced runoff volume. Soil erosion on the tilled plot was lower than that on the fallow plot, because the runoff is reduced. In contrast, sediment concentration in the runoff on the tilled plot was greater than that on the fallow plot. The decrease in soil loss between the tilled and the fallow plots is explained solely by reduced runoff. Indeed, tillage increases the porosity of the soil but diminishes its cohesion.

The scale chosen for this study enables an understanding of runoff and erosion processes in the spaces between benches as well as those of infiltration in the inter-bench channel. It allows the quantification of the effect of this system at the plot scale. This is a first step towards analysis of the impact of benches on hillslope hydrology. When the benches are of the total retention type and no overflows or dike ruptures are observed, water and sediment transfers remain limited to the spaces between benches. For this purpose, a model must be designed capable of simulating runoff flows and erosion as a function of rainfall data as well as the morphological and physical characteristics of the hillslope.

Acknowledgements The authors acknowledge financial support of this study by the IRD and the Aquastress EU Project, the Ministry of Agriculture in Tunisia (DG ACTA) and the CRDA of Siliana.

\section{REFERENCES}

Alaya, K., Viertmann, W. \& Waibel, T. (1993) Les Tabias. GTZ, Tunis, Tunisie.

Albergel, J. \& Rejeb, N. (1997) Les lacs collinaires en Tunisie: enjeux, contraintes et perspectives. Note présentée par J. Albergel. C. R. Acad. Agric. France 1997, 101-104.

Albergel, J., Boufaroua, M., Nasri S. \& Pépin Y. (2003a) Erosion et transport solide dans des petits bassins versants méditerranéens. In: Hydrology of the Mediterranean and Semiarid Regions (Proc. Montpellier Symp., April 2003), 373-379. IAHS Publ. 278. IAHS Press, Wallingford, UK.

Albergel, J., Moussa, R. \& Chahinian, N. (2003b) Les processus hortoniens et leur importance dans la genèse et le développement des crues en zones semi-arides. La Houille Blanche 6, 65-73.

Albergel, J., Nasri, S. \& Boufaroua, M. (1998). Small dams water balance: experimental conditions, data processing and modeling. In: International Seminar on Rain Water Harvesting and Management of Small Reservoirs in Arid and Semiarid Areas (ed. by R. Berndtsson), 47-58. Report 3222, ORSTOM/Hydromed-SAREC-NFR-Lund Univ., Lund, Sweden.

Casenave, A. \& Valentin, C. (1989) Les états de surface de la zone sahélienne, influence sur l'infiltration. Orstom, Coll. Didactiques, Paris, France.

Cerdan, O. (2001) Analyse et modélisation du transfert de particules solides à l'échelle de petits bassins versants cultivés. PhD Thesis, Univ. d'Orléans, Orléans, France.

Cherif, B., Mizouri, M., Aouina, M. S., Khaldi, R. \& Laribi, M. M. (1995) Guide de conservation des eaux et des sols. Ministère de l'Agriculture. Direction de CES. Tun/86/020, Tunis, Tunisie. 
Collinet, J. \& Zante, P. (2005) Analyse du ravinement de bassins versants à retenues collinaires sur sols à fortes dynamiques structurales (Tunisie) Géomorphologie: relief, processus, environnement 1, 61-74.

Dijk, A. I. J. M. V. (2002) Water and sediment dynamics in bench-terraced agricultural steeplands in West Java, Indonesia. PhD Thesis, Vrije Universiteit, Amsterdam, The Netherlands.

Dridi, B. (2000) Impact des aménagements sur la disponibilité des eaux de surface dans le bassin versant du Merguellil (Tunisie Centrale). PhD Thesis, Université Louis Pasteur, Strasbourg, France.

Ennabli, N. (1993) Les aménagements hydrauliques et hydro-agricoles en Tunisie. Institut National Agronomique de Tunisie, Tunis, Tunisie.

Freebairn, D. \& Wockner, G. (1986) A study of soil erosion on vertisols of the eastern Darling Downs, Queensland. I. Effects of surface conditions on soil movement within contour bay catchment. Aust. J. Soil Res. 24, 135-158.

Heusch, B. (1986) Cinquante ans de banquettes de DRS - CES en Afrique du Nord: un bilan. Cah. Orstom, Ser. Pédol. 22(2), $153-162$.

Mansouri, T. (2001) Modélisation spatialisée des écoulements et du transport solide des bassins versants des lacs collinaires de la Dorsale tunisienne et du Cap Bon. Thèse de Doctorat, Université de Tunis El Manar, Tunis, Tunisie.

Nahal, I. (1975) Principes de conservation du sol. Collection de géographie applicable, Masson, Paris, France.

Nasri, S. (2002) Hydrological effects of water harvesting techniques. A study of tabias, soil contour ridges and hill reservoirs in Tunisia. $\mathrm{PhD}$ thesis, Lund University, Lund, Sweden.

Nasri, S. (2007) Caractéristiques et impacts hydrologiques de banquettes en cascade sur un versant semi-aride en Tunisie centrale. Hydrol. Sci. J. 52(6), 1134-1145.

Nasri, S., Lamachère, J.-M. \& Albergel, J. (2004) Impact des banquettes sur le ruissellement d'un petit bassin versant. Rev. Sci. Eau 17(2), 265-289.

Prinz, D. (1999) Water harvesting techniques in the Mediterranean region. In: Rain Water Harvesting and Management of Small Reservoirs in Arid and Semiarid Areas (ed. by R. Berndtsson), 151-163. Report 3222, ORSTOM/HydromedSAREC-NFR-Lund Univ., Lund, Sweden.

Remenieras, G. (1972) L'Hydrologie de l'ingénieur (troisième édn). Eyrolles, Paris, France.

Roose, E. (1994) Introduction à la gestion conservatoire de l'eau, de la biomasse et de la fertilité des sols (GCES). Bulletin Pédologique de la FAO no. 70. FAO, Rome. Italie.

Sharda, V. N. \& Samra, J. S. (2002) Hydrological simulation of a conservation bench terrace system in a subhumid climate. Hydrol. Sci. J. 47(4), 549-561.

Received 31 May 2007; accepted 18 February 2008 